\title{
REPRESENTASI KANDIDAT GUBERNUR NTB TAHUN 2018 DALAM SURAT KABAR LOMBOK POST: ANALISIS WACANA KRITIS
}

\section{THE REPRESENTATION OF NTB GOVERNOR CANDIDATES IN 2018 ON LOMBOK POST NEWSPAPERS: CRITICAL DISCOURSE ANALYSIS}

\author{
Amalia Magfira, Ahmad Sirulhaq, Rahmad Hidayat \\ Universitas Mataram \\ Jalan Majapahit No. 62 Gomong, Kec. Selaparang, Kota Mataram, \\ Nusa Tenggara Barat \\ Ponsel: 085338643069; Pos el: amaliamagfira98@gmail.com
}

\begin{abstract}
Abstrak
Penelitian ini bertujuan mengungkap representasi pasangan kandidat Gubernur dan Wakil Gubernur NTB pada pemilihan kepala daerah tahun 2018 di surat kabar Lombok Post. Pengungkapan disampaikan secara deskriptif dengan Metode Analisis Wacana Kritis. Model analisis wacana kritis yang digunakan adalah model Teun A. Van Dijk. Data penelitian ini berupa 500 teks berita seputar pasangan kandidat yang bertarung. Karena luasnya populasi data, data dibatasi dengan Teknik Purposive Sampling sehingga hanya 20 teks berita yang ditampilkan dengan pembagian 5 berita untuk setiap pasangan kandidat. Data dikumpulkan dengan Metode Simak dan Teknik Catat. Pada tahap penganalisisan data, digunakan Model Analisis Wacana Kritis versi Teun A. Van Dijk dengan mempraktikkan seluruh komponen elemen struktur. Selanjutnya, data disajikan dengan Metode Formal dan Informal. Berdasarkan hasil penganalisisan data didapatkan simpulan bahwa dalam pemberitaan pasangan kandidat Gubernur dan Wakil Gubernur NTB tahun 2018, Lombok Post menampilkan citra positif seluruh pasangan kandidat. Pada dasarnya, citra negatif juga ditemukan pada pasangan kandidat. Namun, jumlah representasi negatif sangat tidak signifikan.
\end{abstract}

Kata kunci: analisis wacana kritis; surat kabar Lombok Post; pemilihan Gubernur dan Wakil Gubernur NTB 


\begin{abstract}
This study aims to reveal the representation of the both candidate for the Governor and Vice Governor of NTB in the 2018 regional elections on Lombok Post newspaper. Disclosure is delivered descriptively with the Critical Discourse Analysis Method. The critical discourse analysis model used is the Teun A. van Dijk model. The data of this research is in the form of 500 news texts about pairs of candidates who are fighting. Due to the large data population, the data is limited by the Purposive Sampling Technique so that only 20 news texts are displayed with 5 news items for each pair candidate. Data were collected by Listening Method and Recording Technique. At the data analysis stage, the Teun A. van Dijk version of the Critical Discourse Analysis Model was used by practicing all the structural elements. Furthermore, the data is presented with Formal and Informal Methods. Based on the results of data analysis, it was concluded that in reporting on the 2018 NTB Governor and Vice Governor candidate, the Lombok Post displayed a positive image of all candidates. Negative images are also found in reporting the candidate, but, the number of negative representations is not significant.
\end{abstract}

Keywords: critical discourse analysis; Lombok Post Newspaper; election of Governor

\section{Pendahuluan}

Surat kabar merupakan produsen dan penyuplai informasi.

Sebagai penyuplai informasi, surat kabar menjadi media komunikasi sosial yang menghubungkan fakta atau realitas dengan masyarakat pembacanya. Namun, sebagai produsen informasi, fakta dan realitas yang disajikan oleh media telah direkonstruksi sedemikian rupa sehingga terdapat semacam sistem konsep yang diselipkan dalam informasi yang disampaikannya. Sistem konsep inilah yang secara implisit merepresentasikan posisi surat kabar dalam menyajikan informasi kepada masyarakat. Akibatnya, masyarakat dengan pembacaan yang apa adanya akan menerima begitu saja informasi yang diberikan. Oleh karena itu, diperlukan kesadaran kritis dan kemampuan analisis kritis terhadap informasi yang diterima.

Jika pembaca sekadar membaca dan menerima begitu saja isi berita yang ditawarkan, pembaca akan mudah terbawa ideologi/sistem konsep yang diselipkan oleh penulis berita yang memberitakan suatu peristiwa berdasarkan subjektivitas. 
Ideologi penulis dalam juga diketahui bagaimana dan memberitakan sesuatu bisa diketahui dari cara penulis merepresentasikan sesuatu. Dalam Eriyanto (2009: 114), istilah representasi mengarah pada bagaimana seseorang, suatu kelompok, atau gagasan/pendapat tertentu ditampilkan dalam pemberitaan. Representasi ini menyuratkan dua hal. Pertama, apakah seseorang, sekelompok orang, atau gagasan tersebut ditampilkan apa adanya atau diburukkan. Kedua, bagaimana representasi tersebut ditampilkan, dengan kata, kalimat, dan bantuan gambar. Poin utama dalam representasi ialah bagaimana realitas atau objek tersebut ditampilkan. Dengan demikian, pembacaan kritis sangat diperlukan.

Analisis Wacana Kritis (AWK) merupakan alternatif terhadap kebuntuan-kebuntuan dalam analisis media. Seiring dengan perkembangan ilmu pengetahuan, analisis wacana pun diperbarui hingga muncul kajian analisis wacana kritis. Dengan menggunakan analisis wacana kritis, tidak hanya diketahui apa isi teks berita, tetapi mengapa berita itu dihadirkan oleh penulis. Secara lebih dalam, analisis wacana kritis bisa membongkar perspektif politik-ideologis yang tersembunyi dan mengetahui bagaimana penulis surat kabar merepresentasikan objek tulisannya.

Pemilihan gubernur NTB yang merupakan pesta rakyat terbesar di NTB sangat menarik ditelaah dengan perspektif AWK. Selama periode pemilu, para kandidat calon pilgub harus menunjukkan dan mempromosikan diri bahwa mereka pantas untuk mendapatkan jabatan tersebut. Salah satu sarana yang digunakan adalah surat kabar. Dengan demikian, keberpihakan dan usungan politikideologis yang dibawa oleh surat kabar sangat menarik untuk diungkap. Penelitian seputar representasi kandidat pilkada dan surat kabar dengan perspektif AWK sudah pernah dilakukan. Penelitianpenelitian yang dimaksud di antaranya dilakukan oleh Jayanti (2014), Nikmah (2014), Nurasyiyyah dkk., Wati (2014), Jamaludin dkk. (2016), Payuyasa (2017), dan 
Humaira (2018). Sepanjang pengamatan, AWK yang berfokus ke berita pemilihan gubernur NTB pada tahun 2018 di surat kabar Lombok Post belum pernah dilakukan. Oleh sebab itu, penelitian ini akan menerangjelaskan fokus tersebut.

Surat kabar Lombok Post yang menjadi sumber data penelitian ini dipilih karena merupakan salah satu koran terbesar di NTB. Sejak bulan Januari hingga bulan Juni, berita pergerakan, visi dan misi, serta kegiatan kampanye kandidat gubernur NTB mengisi lembar berita surat kabar Lombok Post. Terhitung kurang lebih 500 teks berita yang diterbitkan oleh surat kabar Lombok Post tentang kandidat pemilihan gubernur NTB tahun 2018. Kenyataan ini semakin menarik untuk diteliti dengan perspektif AWK. Sementara itu, versi AWK yang dianut dalam penelitian ini adalah model Teun A. Van Dijk. Model kognisi sosial ini dipilih karena dapat mengungkap perihal praktik produksi wacana dalam surat kabar dengan struktur analisis yang representatif terhadap objek penelitian.
Berdasarkan pemaparan di atas, penelitian ini berfokus mengungkap bagaimana keempat kandidat pemilihan gubernur NTB direpresentasikan dalam surat kabar Lombok Post. Keempat pasangan yang dimaksud adalah 1) Moh. Suhaili Fadil Thohir dan Muhammad Amin, 2) Ahyar Abduh dan Mori Hanafi, 3) Zulkieflimansyah dan Sitti Rohmi Djalillah, dan 4) Moch. Ali Bin Dachlan dan Gede Sakti Amir Murni. Pengungkapan bagaimana pasangan calon kandidat direpresentasikan oleh Lombok Post tidak hanya menguraikan bagaimana dapur produksi ketika wacana akan disajikan, tetapi juga menyadarkan publik bahwa analisis kritis sangat dibutuhkan dalam pembacaan informasi.

\section{Landasan Teori}

\subsection{Analisis Wacana Kritis}

Dalam pandangan kritis, bahasa dipahami sebagai representasi yang berperan dalam membentuk subjek tertentu dan tema-tema wacana tertentu. Oleh karena itu, analisis wacana digunakan untuk membongkar kuasa dalam setiap proses berbahasa. Proses berbahasa 
yang dimaksudkan seperti batasanbatasan apa yang harus dipakai serta topik apa yang dibicarakan. Karena mengandung sudut pandang kritis, analisis wacana kategori ini disebut analisis wacana kritis (Critical Discourse Analysis/CDA) (Eriyanto, 2009: 6).

Dapat dikatakan bahwa analisis wacana kritis adalah jenis analisis wacana yang mempelajari pengungkapan penyalahgunaan kekuasaan, dominasi, dan ketidaksetaraan yang dipraktikkan dan direproduksi dalam bentuk teks tertulis maupun lisan (lihat Schiffrin dkk., 2001: 352). Dalam bahasa tulis digunakan istilah kalimat, sedangkan ragam bahasa lisan berupa ujaran (Rani, dkk., 2006: 9). Hal ini karena tujuan utama analisis kritis adalah mengkaji bagaimana kekuasaan disalahgunakan. Selain itu, AWK menelaah bagaimana ketidakadilan terjadi dan dipelihara melalui teks dalam konteks sosial politik. Analisis wacana kritis memiliki peranan penting dalam melawan arus yang mendominasi ketidakadilan sosial. Analisis wacana kritis merupakan pendekatan konstruktivis sosial (Eriyanto, 2009: ix).

\subsection{Konsep Analisis Wacana Kritis Model Teun A. van Dijk}

Model yang diperkenalkan oleh

Teun A. Van Dijk dikenal juga sebagai "kognisi sosial". Menurutnya, penelitian terhadap wacana tidak cukup didasarkan pada analisis teks semata, tetapi suatu praktik produksi yang harus diamati. Penelitian atas wacana juga harus melihat bagaimana produksi teks itu bekerja dan mengapa teks tersebut hadir. Van Dijk menerangkan wacana memiliki tiga dimensi/bangunan, yakni teks, kognisi sosial, dan konteks sosial. Gabungan ketiga dimensi tersebut menjadi inti analisis dalam model Van Dijk (Eriyanto, 2009: 221224).

a. Teks

Bagi Van Dijk, teks terdiri atas beberapa struktur/tingkatan. Pertama adalah struktur makro yang mengamati atau melihat makna umum suatu teks, yaitu elemen topik atau tema. Kedua adalah superstruktur yang berhubungan dengan kerangka suatu teks, yaitu 
bagaimana bagian-bagian teks tersusun secara utuh. Ketiga adalah struktur mikro, yaitu makna wacana yang bisa diamati dari bagian terkecil suatu teks. Kata, kalimat, proposisi, anak kalimat, parafrasa, dan gambar merupakan bagian terkecil tersebut.

\section{Tabel 1}

Struktur Teks

\section{Struktur Makro}

Makna global dari suatu teks yang dapat diamati dari topik/tema yang diangkat oleh suatu teks.

\section{Superstruktur}

Kerangka suatu teks, seperti bagian pendahuluan, isi, penutup, dan kesimpulan.

\section{Struktur Mikro}

Makna lokal dari suatu teks yang dapat diamat dari pilihan kata, kalimat, dan gaya yang dipakai oleh suatu teks.

Sumber: Eriyanto, 2009: 227

b. Kognisi Sosial

Kognisi sosial berkaitan dengan bagaimana suatu teks diproduksi. Artinya, analisis wacana tidak hanya berfokus pada struktur teks saja, melainkan mengungkap praktik di balik struktur itu. Menurut Van Dijk, untuk membongkar makna tersembunyi dari teks dibutuhkan analisis konteks dan kognisi sosial. Hal itu dikarenakan struktur wacana berisi sejumlah makna, pendapat, dan ideologi. Dalam hal ini, wartawan yang berperan sebagai pembuat teks sering kali dianggap tidak netral.

c. Analisis Sosial

Untuk meneliti teks wacana, perlu dilakukan suatu analisis dengan meneliti bagaimana dan mengapa wacana diproduksi dan dikonstruksi dalam masyarakat karena wacana merupakan bagian dari masyarakat dan berkembang di masyarakat. Menurut Van Dijk, ada dua poin utama dalam analisis mengenai masyarakat ini, yakni praktik kekuasaan dan akses memengaruhi wacana.

\section{Metode Penelitian}

Penelitian ini menggunakan pisau bedah AWK sebagai metode penelitiannya. AWK dapat dikatakan sebagai metode dalam penelitian ilmu sosial (Wodak dan Meyer, 2001: 121). Pisau bedah AWK akan menguraikan bagaimana pihak surat kabar Lombok Post merepresentasikan keempat pasangan kandidat pemilihan Gubernur NTB tahun 2018. Data dalam penelitian ini adalah teks berita kandidat pemilihan 
Gubernur NTB tahun 2018 dalam surat kabar Lombok Post. Data difokuskan pada berita yang berkaitan dengan keempat pasangan yang berkompetisi memperebutkan kursi gubernur dan wakil gubernur. Data dalam penelitian ini berbentuk wacana, kalimat, frasa, dan kata yang berhubungan dengan variabel penelitian.

Sumber data dalam penelitian ini adalah surat kabar harian Lombok Post terbitan tahun 2018 periode Januari sampai dengan Mei 2018. Lombok Post dipilih sebagai sumber data karena merupakan salah satu koran terbesar di NTB dan sudah dikenal merata oleh khalayak pembaca. Berdasarkan hasil penelusuran dan penghitungan jumlah teks berita, terdapat kurang lebih 500 teks berita mengenai pemilihan Gubernur NTB tahun 2018. Oleh karena itu, populasi dalam penelitian ini adalah 500 teks berita. Karena jumlah populasi yang relatif banyak, peneliti mengambil sampel sebagai bahan analisis. Penentuan sampel menggunakan teknik purposive sampling. Sampel yang dipilih berjumlah 20 teks berita dengan pembagian 5 wacana teks berita untuk setiap pasangan kandidat. Penentuan sampel sangat memperhatikan kebutuhan berdasarkan pisau analisis yang digunakan.

Pengumpulan data dalam penelitian ini menggunakan Metode Simak dengan Teknik Catat (Mahsun, 2017: 91). Peneliti menyimak data kebahasaan berupa unsur leksikal dan unsur gramatikal dalam wacana berita sesuai dengan variabel penelitian. Selanjutnya, pada tahapan penganalisisan data, semua data diinterpretasikan dengan koridor model AWK Van Dijk pada setiap elemen struktur. Interpretasi pada keseluruhan struktur tersebut selanjutnya dikonstruksikan menjadi sebuah simpulan untuk masingmasing pasangan calon. Simpulan yang dimaksud adalah bagaimana pasangan calon tersebut direpresentasikan sebagaimana tujuan penelitian ini. Selanjutnya, pada penyajian hasil penganalisisan data digunakan metode formal dan metode informal (Mahsun, 2017: 252). 
Tabel 2

Klasifikasi Analisis Berita Berdasarkan Struktur Wacana Van Dijk

\begin{tabular}{|l|l|l|l|}
\hline No. & $\begin{array}{r}\text { Elemen } \\
\text { Wacana }\end{array}$ & Kutipan & Analisis \\
\hline & & & \\
\hline & & & \\
\hline
\end{tabular}

\section{Pembahasan}

Bagian pembahasan berisikan hasil analisis berita tentang kandidat Pilgub NTB 2018 yang diterbitkan oleh surat kabar Lombok Post. Berita kandidat Pilgub NTB terbit sejak bulan Januari sampai dengan bulan Mei. Hasil analisis ini menjelaskan bagaimanakah surat kabar Lombok Post merepresentasikan keempat kandidat pemilihan gubernur NTB tahun 2018. Pada akhirnya akan diketahui apakah terdapat unsur politik-ideologis serta gambaran citra setiap kandidat Pilgub NTB tahun 2018 dalam surat kabar Lombok Post.

\subsection{Representasi Kandidat Pemilihan Gubernur Moh. Suhaili Fadil Thohir dan Muhammad Amin}

Tabel 3

Klasifikasi Analisis Teks Berita "Baliho Suhaili-Amin Catut Lambang Muhammadiyah"

\begin{tabular}{|l|c|l|l|}
\hline No. & $\begin{array}{l}\text { Elemen } \\
\text { Wacana }\end{array}$ & \multicolumn{1}{|c|}{ Kutipan } & \multicolumn{1}{|c|}{ Analisis } \\
\hline 1. & Tema & $\begin{array}{l}\text { Baliho Suhaili-Amin Catut } \\
\text { Lambang Muhammadiyah }\end{array}$ & $\begin{array}{l}\text { 1. Lombok Post memarginalkan } \\
\text { pasangan Suhaili-Amin. Lombok } \\
\text { Post secara terbuka menyebutkan } \\
\text { nama pasangan tersebut. } \\
\text { 2. Pertentangan antara pihak Suhaili- } \\
\text { Amin dan ormas Muhammadiyah. } \\
\text { Serta penonjolan ormas tersebut } \\
\text { dibandingkan ormas lainnya. }\end{array}$ \\
\hline 2. & Bentuk & $\begin{array}{l}\text { Sebuah baliho Suhaili-Amin } \\
\text { memampang } \\
\text { Muhammadiyah. }\end{array}$ & $\begin{array}{l}\text { Penggunaan bentuk kalimat aktif } \\
\text { sehingga aktor/pelaku terekspos dan } \\
\text { diketahui oleh pembaca. Bentuk } \\
\text { kalimat yang aktif bisa membuat } \\
\text { pembaca fokus pada subjek dan } \\
\text { korban. }\end{array}$ \\
\hline
\end{tabular}




\begin{tabular}{|c|c|c|c|}
\hline 3. & Leksikon & $\begin{array}{l}\text { 1). Sebuah baliho Suhaili- } \\
\text { Amin memampang logo } \\
\text { Muhammadiyah. Baliho yang } \\
\text { berada di Kecamatan } \\
\text { Kopang, Lombok Tengah itu } \\
\text { memasang logo sejumlah } \\
\text { partai, termasuk ormas } \\
\text { keagamaan NU dan } \\
\text { Muhammadiyah. } \\
\text { 2). Terpisah, HM Amin } \\
\text { mengatakan dia dan tim } \\
\text { belum mengetahui adanya } \\
\text { pemasangan logo tanpa izin } \\
\text { itu. }\end{array}$ & $\begin{array}{l}\text { 1). Organisasi masyarakat yang } \\
\text { paling berpengaruh ialah ormas } \\
\text { berbasis agama. Ketika leksikon } \\
\text { logo Muhammadiyah terpampang } \\
\text { nyata pada awal kalimat berita, akan } \\
\text { menjadi daya tarik tersendiri. Meski } \\
\text { kenyataannya terdapat logo sejumlah } \\
\text { partai. } \\
\text { 2). Kata terpisah menunjukkan tidak } \\
\text { adanya keterkaitan dengan paragraf } \\
\text { sebelumnya. Lombok } \\
\text { memberikan ruang berita kepada } \\
\text { Suhaili-Amin untuk mengklarifikasi } \\
\text { posisi mereka } \\
\text { mencantumkan pernyataan langsung } \\
\text { dari Amin selaku calon wakil } \\
\text { gubernur, guna tetap menjaga citra } \\
\text { positif. }\end{array}$ \\
\hline 4. & Koherensi & $\begin{array}{l}\text { 1). Padahal dalam Milad ke } \\
105 \text { Masehi/ } 108 \text { Hijriah } \\
\text { yang dipusatkan di Mataram, } \\
\text { Desember } 2017 \text { lalu, } \\
\text { ditegaskan Muhammadiyah } \\
\text { tidak terlibat politik praktis. } \\
\text { Ketua Muhammadiyah NTB } \\
\text { H Falahuddin memastikan } \\
\text { netralitas Muhammadiyah tak } \\
\text { perlu lagi dipertanyakan. } \\
\text { 2) Namun, yang pasti tak } \\
\text { pernah ada instruksi ataupun } \\
\text { konfirmasi darinya ataupun } \\
\text { HM Suhalili FT sebagai } \\
\text { bakal pasangan calon untuk }\end{array}$ & $\begin{array}{l}\text { 1). Kata padahal merupakan kata } \\
\text { sambung untuk menunjukkan } \\
\text { pertentangan. Hal itu menunjukkan } \\
\text { bahwa Suhaili-Amin tidak mematuhi } \\
\text { arahan dari pihak Muhammadiyah } \\
\text { yang mendeklarasikan bahwa } \\
\text { mereka netral dalam dunia politik. } \\
\text { 2). Penggunaan kata hubung namun } \\
\text { yang diikuti oleh kosakata yang } \\
\text { pasti merupakan bentuk ekspresi } \\
\text { penekanan bahwa Amin dan Suhaili } \\
\text { tidak pernah menginstruksikan } \\
\text { perihal pencantuman lambang } \\
\text { Muhammadiyah. Penulis berita tetap } \\
\text { menjaga citra pasangan Suhaili- }\end{array}$ \\
\hline
\end{tabular}




\begin{tabular}{|c|c|c|c|}
\hline & & memasangnya. & $\begin{array}{l}\text { Amin, bahwa mereka tidak terlibat } \\
\text { langsung. }\end{array}$ \\
\hline 5. & Kata Ganti & $\begin{array}{l}\text { 1). Dia menegaskan warga } \\
\text { Muhammadiyah.... } \\
\text { 3). Dia menduga ada } \\
\text { simpatisan yang secara } \\
\text { pribadi memasangnya. } \\
\text { Menghindari polemik } \\
\text { berkepanjangan, ia berjanji } \\
\text { segera mengganti baliho } \\
\text { tersebut. }\end{array}$ & $\begin{array}{l}\text { Terdapat penggunaan kata ganti dia } \\
\text { dan ia. Kata ganti ini mengarah pada } \\
\text { persona tunggal yang dibicarakan, di } \\
\text { luar pembicaraan dan kawan bicara. } \\
\text { Penulis menggunakan elemen kata } \\
\text { ganti sebagai alat untuk } \\
\text { menunjukkan posisi seseorang dalam } \\
\text { wacana. }\end{array}$ \\
\hline 6. & Metafora & $\begin{array}{l}\text {... namun ormas yang satu } \\
\text { ini pantang nyemplung } \\
\text { langsung ke ranah politik. }\end{array}$ & $\begin{array}{l}\text { Kata nyemplung merupakan bahasa } \\
\text { gaul yang mengarah pada suatu } \\
\text { tindakan memasukan atau mengikut } \\
\text { sertakan diri dalam sebuah kejadian. } \\
\text { Itu adalah pernyataan penolakan diri } \\
\text { pihak Muhammdiyah untuk ikut } \\
\text { campur dalam ranah politik. }\end{array}$ \\
\hline 7. & Ekspresi & \begin{tabular}{lr} 
Bahkan & \multicolumn{2}{c}{ dibarengi } \\
permintaan untuk & segera \\
menurunkan baliho yang & logo \\
memuat & \\
Muhammadiyah itu.
\end{tabular} & $\begin{array}{l}\text { Penggunaan kata } \\
\text { merupakan bentuk } \\
\text { penekanan, karena kata bahkan } \\
\text { digunakan untuk menyatakan } \\
\text { penguatan. Muhammadiyah sebagai } \\
\text { korban memohon untuk menurunkan } \\
\text { baliho tersebut karena tidak ingin } \\
\text { dipandang buruk oleh masyarakat. }\end{array}$ \\
\hline 8. & Skema & - & $\begin{array}{l}\text { Lombok Post menggunakan skema } \\
\text { summary yang ditandai oleh dua } \\
\text { elemen yakni judul dan lead. Jika } \\
\text { dilihat pada keseimbangan penulisan } \\
\text { berita, Lombok Post pro kepada } \\
\text { Muhammadiyah dengan } \\
\text { menghadirkan jumlah pernyataan }\end{array}$ \\
\hline
\end{tabular}




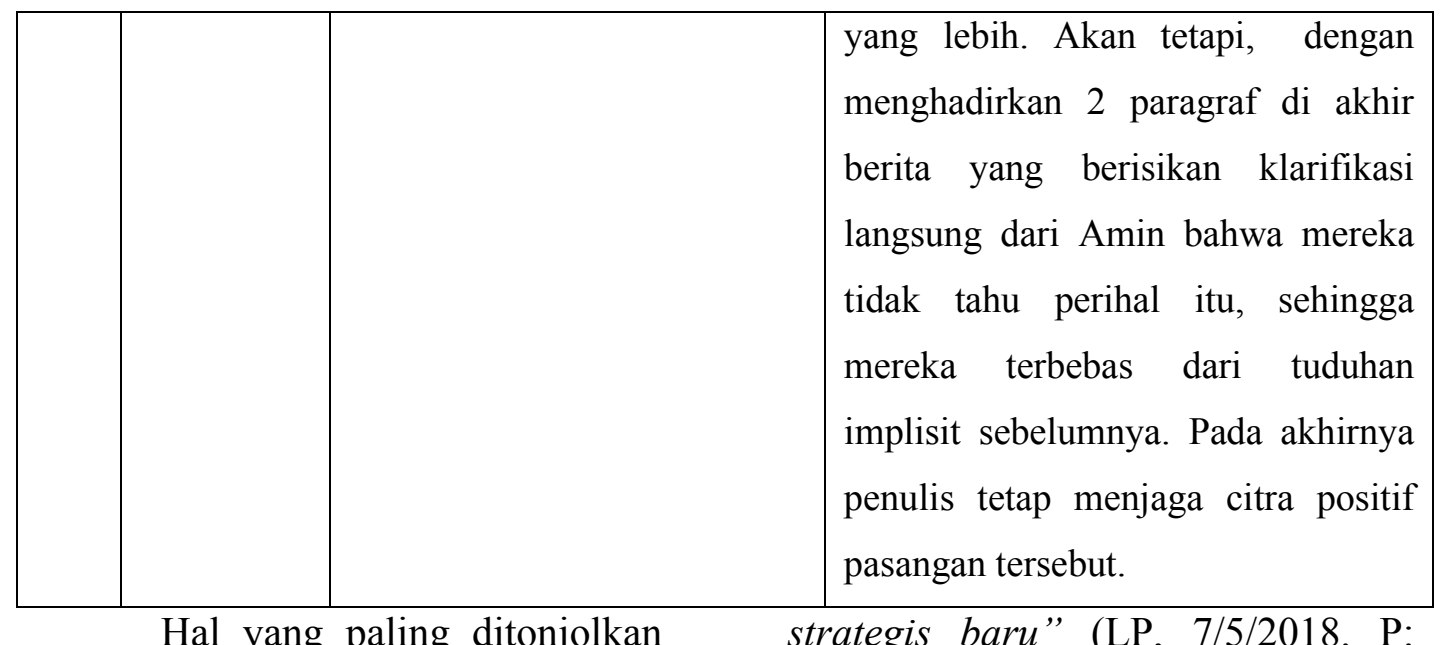

ialah sosok HM Amin yang sebelumnya pernah menjabat sebagai wakil gubernur NTB mendampingi TGB. Penonjolan sosok Amin ini merupakan suatu usaha melestarikan, menjaga, dan mengamalkan apa yang ada agar terjaga keadaannya, meski dengan sedikit perubahan. “.... Kini selepas TGB, bersama Suhaili, keduanya menyusun langkah
11). Amin adalah satu-satunya orang yang bisa melanjutkan pembangunan NTB karena beliaulah yang telah memulainya bersama TGB. Lombok Post memberitakan mereka sebagai calon yang paling komplet, kenyang pengalaman memimpin, dan bergelimang prestasi. Karena Suhaili pun pernah memimpin Lombok Tengah selama dua periode.

\subsection{Representasi Kandidat Pemilihan Gubernur Ahyar Abduh dan Mori Hanafi}

\section{Tabel 4}

Klasifikasi Analisis Teks Berita "PAN Digenggam Ahyar-Mori (Peluang Calon Kecil Mengecil)"

\begin{tabular}{|l|c|lr|ll|}
\hline No. & Elemen & \multicolumn{2}{|c|}{ Kutipan } & \multicolumn{3}{|c|}{ Analisis } \\
& Wacana & \multicolumn{2}{|l|}{} \\
\hline 1. & Tema & PAN & Digenggam & Tema umum berita ini adalah \\
& & Ahyar-Mori & (Peluang & umproklamasikan bahwa PAN sudah \\
& & Calon & Kelima & berada di pihak Ahyar-Mori. \\
& & Mengecil) & & Kemudian akan disusul oleh PDIP dan \\
& & & PKB. Subtopik, ialah Peluang Calon \\
& & & Kelima Mengecil. Subtopik ini \\
\hline
\end{tabular}




\begin{tabular}{|c|c|c|c|}
\hline & & & $\begin{array}{l}\text { mendukung, memperkuat bahkan } \\
\text { membentuk topik utama, karena } \\
\text { Ahyar-Mori, calon lain mau tidak mau } \\
\text { harus kalah sebelum berperang. }\end{array}$ \\
\hline 2. & $\begin{array}{l}\text { Bentuk } \\
\text { Kalimat }\end{array}$ & $\begin{array}{l}\text { Dengan PAN yang telah } \\
\text { memastikan dukungan, } \\
\text { plus PDIP dan PKB } \\
\text { yang segera menyusul } \\
\text { dalam satu dua hari ini }\end{array}$ & $\begin{array}{l}\text { Paragraf pertama yang diawali oleh } \\
\text { bentuk kalimat aktif menunjukkan } \\
\text { aktor berita yang dibicarakan secara } \\
\text { terang-terangan. Berbeda apabila } \\
\text { penulis menggunakan bentuk kalimat } \\
\text { pasif, biasanya tempat untuk } \\
\text { menyembunyikan aktor berita. }\end{array}$ \\
\hline 3. & $\begin{array}{c}\text { Koherensi } \\
\text { Kondisional }\end{array}$ & $\begin{array}{l}\text {..., hampir dipastikan } \\
\text { tak ada calon kelima } \\
\text { yang akan muncul. } \\
\text { Karena praktis hanya } \\
\text { tersisa Hanura yang } \\
\text { sebenarnya sudah } \\
\text { memilih Ali-Sakti dan } \\
\text { PBB yang mencoba } \\
\text { memajukan KH Zulkifli } \\
\text { Muhadli. }\end{array}$ & $\begin{array}{l}\text { Pemakaian koherensi kondisional } \\
\text { ditandai oleh pemakaian anak kalimat } \\
\text { sebagai penjelas. "hampir dipastikan } \\
\text { tak ada calon kelima yang akan } \\
\text { muncul" merupakan anak kalimat. } \\
\text { Anak kalimat di atas menjadi cerminan } \\
\text { kepentingan penulis. Melalui hal itu ia } \\
\text { dapat memberi keterangan yang baik } \\
\text { bagi Ahyar-Mori dan memberi } \\
\text { keterangan buruk bagi calon kelima } \\
\text { yang dikatakan tidak ada peluang. }\end{array}$ \\
\hline 4. & Latar & $\begin{array}{l}\text { Jika kondisi ini bertahan } \\
\text { hingga masa } \\
\text { pendaftaran, nama Kiai } \\
\text { Zul dan Prof Farouk } \\
\text { Muhammad, dua } \\
\text { nama terakhir yang } \\
\text { masih coba mengintip } \\
\text { peluangnya praktis } \\
\text { tertutup (yuk/r8). }\end{array}$ & $\begin{array}{l}\text { Paragraf ini berisikan kesimpulan } \\
\text { akhir bahwa dengan adanya dukungan } \\
\text { dari PAN, PDIP, dan PKB pada } \\
\text { Ahyar-Mori, tertutuplah peluang bagi } \\
\text { Kiai Zul dan Prof. Farouk } \\
\text { Muhammad. Hal yang perlu } \\
\text { diperhatikan ialah cara terjadinya } \\
\text { praktik bahasa yang merupakan bagian } \\
\text { dari representasi dengan dicantumkan } \\
\text { nama secara jelas. }\end{array}$ \\
\hline 5. & Skema & - & Teks berita ini berkategori skema \\
\hline
\end{tabular}




\begin{tabular}{|l|l|l|}
\hline & $\begin{array}{l}\text { story. Story yaitu isi berita secara } \\
\text { keseluruhan yang secara hipotetik } \\
\text { memiliki dua subkategori. Pertama } \\
\text { berupa situasi, yakni proses atau } \\
\text { jalannya peristiwa. Kedua, berupa } \\
\text { komentar yang ditampilkan dalam } \\
\text { teks. }\end{array}$ \\
\hline
\end{tabular}

Penulis berita Lombok Post menggambarkan Ahyar-Mori sebagai pasangan yang memiliki rasa perhatian, simpati, dan empati tanpa memandang status sosial. "NTB juga harus berpihak pada berbagai suku yang ada di daerah ini, Sasak, Samawa, dan Mbojo, serta suku-suku lainnya. "Intinya NTB untuk semua," ujarnya” (LP, 14/5/018. P: 4). Terlihat pula pada kutipan berita lainnya “... Tak lain karena program mereka yang pro rakyat dan nyata" (LP, 13/3/2018. P: 10). Hal itu menjadi poin utama dari pasangan ini. Keduanya pun menyatakan akan adil dan merata pada setiap daerah di NTB, dari Ampenan hingga Sape. Pasangan ini merupakan campuran suku Sasak dan Mbojo, karena itu diibaratkan dwi tunggal representasi Pulau Lombok dan Sumbawa. Ahyar berasal dari Lombok dan Mori putra Bima. Mereka pun diberitakan sebagai jawara Instagram. Selain itu, sebagai pasangan yang paling banyak didukung oleh partai politik, yakni sembilan partai politik.

\subsection{Representasi Kandidat Pemilihan Gubernur Zulkieflimansyah dan Sitti Rohmi Djalillah}

Tabel 5

Klasifikasi Analisis Teks Berita "Zul Rohmi Berkhidmat untuk Rakyat"

\begin{tabular}{|l|c|l|l|}
\hline No. & $\begin{array}{c}\text { Elemen } \\
\text { Wacana }\end{array}$ & \multicolumn{1}{c|}{ Kutipan } & \multicolumn{1}{c|}{ Analisis } \\
\hline 1. & Tema & $\begin{array}{l}\text { Zul-Rohmi Bekhidmat } \\
\text { untuk Rakyat }\end{array}$ & $\begin{array}{l}\text { Tema berita ialah menggambarkan } \\
\text { tindakan pengabdian diri Zul-Rohmi } \\
\text { untuk rakyat. Dalam konteks topik, } \\
\end{array}$ \\
& & $\begin{array}{l}\text { berkhidmat mengarah pada bentuk } \\
\text { ibadah Zul-Rohmi untuk memenuhi }\end{array}$ \\
\hline
\end{tabular}




\begin{tabular}{|c|c|c|c|}
\hline & & & $\begin{array}{l}\text { kewajibannya kepada Tuhan dan } \\
\text { manusia. Ketika Zul-Rohmi menjadi } \\
\text { pemimpin NTB, mereka akan } \\
\text { memenuhi kewajiban sebagai } \\
\text { pemimpin. Selain itu, dengan } \\
\text { penggunaan kata rakyat } \\
\text { menunjukkan bahwa Zul-Rohmi } \\
\text { calon yang peduli dengan rakyat. }\end{array}$ \\
\hline 2. & Leksikon & 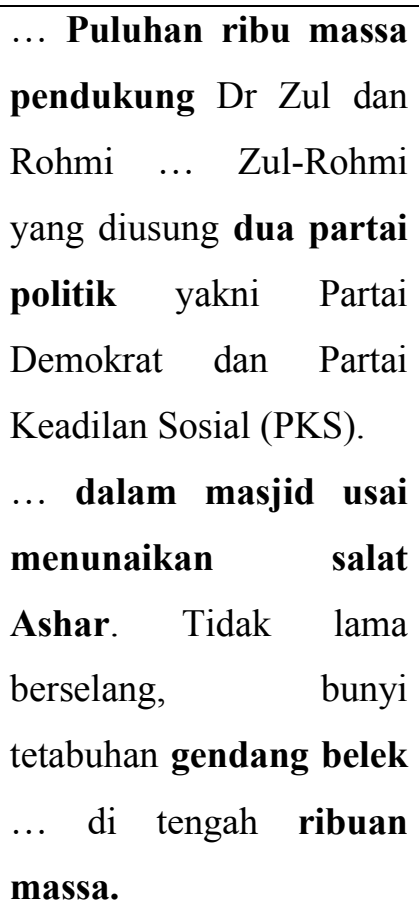 & $\begin{array}{l}\text { Berdasarkan pendeksripsian } \\
\text { puhuhan ribu massa dan dua } \\
\text { partai politik akan memberikan } \\
\text { nilai dan citra positif bagi pasangan } \\
\text { Zul-Rohmi. Ditambah dengan } \\
\text { sentuhan bahasa yang sarat akan } \\
\text { keagamaan dan kebudayaan. Dengan } \\
\text { membaca dua paragraf awal berita, } \\
\text { Lombok Post menggambarkan betapa } \\
\text { riuh, ramai, dan luar biasanya } \\
\text { antuasis pendukung Zul-Rohmi, } \\
\text { padahal masa itu masih dalam tahap } \\
\text { pendaftaran diri. }\end{array}$ \\
\hline 3. & Leksikon & $\begin{array}{l}\text { Tidak sampai di situ, } \\
\text { massa yang umumnya } \\
\text { terdiri dari ibu-ibu } \\
\text { pengajian, kader PKS } \\
\text { dan Demokrat serentak } \\
\text { melantunkan shalawat } \\
\text { selama proses } \\
\text { pendaftaran berlangsung. } \\
\text { Sementara itu, Zul- } \\
\text { Rohmi disambut hangat } \\
\text { oleh lima komisioner }\end{array}$ & $\begin{array}{l}\text { Penggambaran awal menunjukkan } \\
\text { kelanjutan dari aksi massa } \\
\text { pendukung Zul-Rohmi. Upaya lain } \\
\text { pihak Lombok Post yang ingin } \\
\text { memperlihatkan sisi agamais dari } \\
\text { massa pendukung Zul-Rohmi. } \\
\text { Pemberitaan yang seperti itu bagian } \\
\text { dari elemen wacana leksikon, yakni } \\
\text { bagaimana pemilihan bahasa yang } \\
\text { dilakukan oleh pihak Lombok Post. }\end{array}$ \\
\hline
\end{tabular}




\begin{tabular}{|c|c|c|c|}
\hline & & KPU NTB. & \\
\hline 4. & Praanggapan & 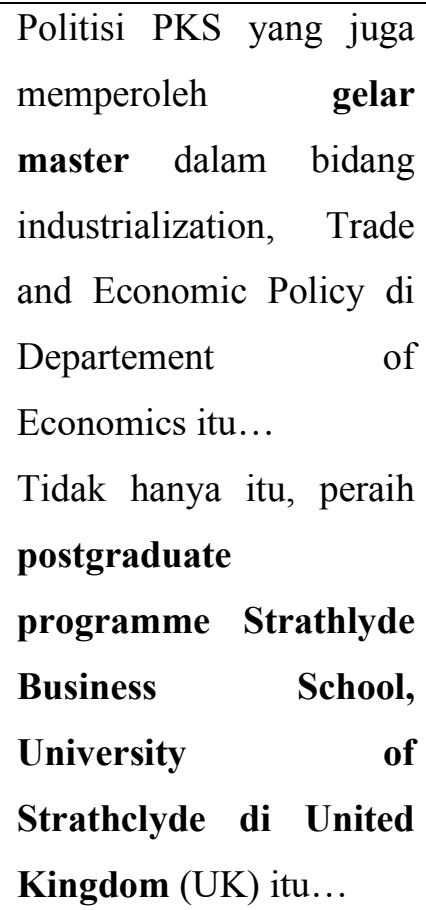 & $\begin{array}{l}\text { Orang yang berpendidikan dianggap } \\
\text { sebagai orang yang tinggi derajatnya. } \\
\text { Maka penggambaran latar } \\
\text { pendidikan Zulkieflimansyah yang } \\
\text { dilakukan oleh Lombok Post } \\
\text { merupakan salah satu upaya } \\
\text { terselubung untung menarik } \\
\text { simpatisan. Karena itu, kehadiran } \\
\text { penjelasan dari latar belakang } \\
\text { pendidikan Zul sebagai anak kalimat } \\
\text { menyebabkan kutipan itu menjadi } \\
\text { bagian dari elemen wacana } \\
\text { pranggapan. }\end{array}$ \\
\hline 5. & Leksikon & $\begin{array}{l}\text { Terpisah, Siti Rohmi } \\
\text { Djalillah memaparkan } \\
\text { komitmennya kepada } \\
\text { perempuan NTB. } \\
\ldots \\
\text { perempuan punya } \\
\text { mimpi besar untuk } \\
\text { membangun NTB lebih } \\
\text { baik lagi. Dia yakin dapat } \\
\text { berjuang memajukan } \\
\text { NTB dengan restu dan } \\
\text { dukungan para } \\
\text { perempuan NTB. }\end{array}$ & $\begin{array}{l}\text { Dengan majunya sosok Rohmi, satu- } \\
\text { satunya yang maju sebagai wakil } \\
\text { gubernur melahirkan cerita baru. } \\
\text { Perempuan bukan lagi kaum yang } \\
\text { lemah, yang hanya bekerja di rumah } \\
\text { saja. Akan tetapi, perempuan bisa } \\
\text { lebih dari itu, menciptakan mimpi } \\
\text { besar, serta memiliki hak untuk } \\
\text { memujudkannya. Citra seperti itulah } \\
\text { yang hendak dilahirkan oleh Lombok } \\
\text { Post. Hal itu terlihat pada } \\
\text { penggambaran sosok Rohmi yang } \\
\text { dijelaskan dengan detail. }\end{array}$ \\
\hline 6. & Skema & - & $\begin{array}{l}\text { Lombok Post memakai skema } \\
\text { peristiwa. Peristiwa pendaftaran diri } \\
\text { Zul-Rohmi yang dikawal oleh ribuan } \\
\text { massa pendukung, peristiwa proses } \\
\text { pendaftaran diri, dan peristiwa }\end{array}$ \\
\hline
\end{tabular}




\begin{tabular}{l|ll}
\hline & & lainnya waktu itu. \\
\hline Rohmi merupakan satu- & nanti, banyak perempuan NTB yang \\
satunya perempuan yang terlibat & diamanahkan menjadi pemimpin \\
dalam Pilgub NTB 2018 menjadi hal & (LP, 6/4/2018. P: 5). Rohmi \\
utama yang disuarakan oleh Lombok & direpresentasikan sebagai bukti nyata \\
Post. Dengan tema utama kesetaraan & kesuksesan perempuan NTB berkat \\
gender. Pentingnya pendidikan bagi & pendidikan yang tinggi. Terpisah dari \\
perempuan menjadi hal lainnya yang & hal itu, akibat kampanye dialogis \\
ditonjolkan. "Untuk itu, lanjut & dengan strategi blusukan, pasangan \\
Rohmi, pendidikan perempuan harus & ini dikatakan sebagai pasangan yang \\
jadi utama. Dia mendorong kaum & pintar. Sosok Zul selaku cagub pun \\
perempuan NTB untuk meniti karir & direpresentasikan sebagai sosok yang \\
tinggi. Tidak menutup kemungkinan & berpretasi dan berpendidikan tinggi.
\end{tabular}

\subsection{Representasi Kandidat Pemilihan Gubernur Moch. Ali Bin Dachlan dan Gede Sakti Amir Murni}

Tabel 6

Klasifikasi Analisis Teks Berita "Waktu Ali-Sakti Mepet (Verifikasi Faktual, Ali-Sakti Wajib Datangkan Pemilik KTP)"

\begin{tabular}{|l|c|l|l|l|}
\hline No. & Elemen & \multicolumn{2}{|c|}{ Kutipan } & \multicolumn{2}{|c|}{ Analisis } \\
\hline 1. & Wacana & Tema & $\begin{array}{l}\text { Waktu Ali-Sakti Mepet } \\
\text { (Verifikasi Faktual, Ali- } \\
\text { Sakti Wajib Datangkan } \\
\text { Pemilik KTP) }\end{array}$ & $\begin{array}{l}\text { Secara ekspilisit, topik ini } \\
\text { menyudutkan dan membatasi } \\
\text { gerak-gerik Ali-Sakti. Kata mepet } \\
\text { mengarah pada keadaan mendesak } \\
\text { diangkat menjadi topik berita. } \\
\text { Digambarkan bahwa Ali-Sakti } \\
\text { berada pada siatuasi yang dikejar } \\
\text { waktu. Kemudian subtopik yang } \\
\text { dihadirkan menambah kesan } \\
\text { keterbatasan ruang bagi Ali-Sakti. } \\
\text { Sehingga tema besarnya ialah } \\
\text { pasangan Ali-Sakti yang berada } \\
\text { pada situasi yang krusial. }\end{array}$ \\
\hline
\end{tabular}




\begin{tabular}{|c|c|c|c|}
\hline 2. & $\begin{array}{c}\text { Leksikon } \\
\text { dan } \\
\text { Pengingkaran }\end{array}$ & $\begin{array}{l}\text {... .Namun, pasangan } \\
\text { Ali-Sakti punya waktu } \\
\text { yang mepet untuk } \\
\text { menyerahkan kekurangan } \\
\text { dukungan yang } 101.026 \\
\text { KTP. } \\
\text { Dukungan sudah harus } \\
\text { sampai di KPU paling } \\
\text { telat 20 Januari } 2018 . \\
\text { Namun, waktu yang } \\
\text { hanya dua pekan tersebut } \\
\text { tak jadi soal bagi ketua } \\
\text { Tim Pemenang Ali-Sakti } \\
\text { Basri Mulyani. }\end{array}$ & $\begin{array}{l}\text { Ali-sakti digambarkan berada pada } \\
\text { situasi yang mengkhawatirkan. } \\
\text { Klausa pasangan Ali-Sakti } \\
\text { punya waktu mepet menunjukkan } \\
\text { kondisi tersebut. Ali-Sakti hanya } \\
\text { memiliki sedikit waktu untuk } \\
\text { menyerahkan KTP. Itu merupakan } \\
\text { bagian dari elemen leksikon, yakni } \\
\text { bagaimana wartawan memilih kata- } \\
\text { kata untuk menggambarkan } \\
\text { sesuatu. Kehadiran kata namun, } \\
\text { mengarah bahwa akhirnya Ali- } \\
\text { Sakti bisa segera mendaftarkan } \\
\text { dirinya untuk maju pada Pilgub } \\
\text { NTB 2018. }\end{array}$ \\
\hline 3. & $\mathrm{Mal}$ & $\begin{array}{l}\text { Basis NW Anjani menjadi } \\
\text { yang utama digarap. } \\
\text { Seperti diketahui, Gde } \\
\text { Sakti adalah salah satu } \\
\text { figur utama di pondok } \\
\text { Pesanteran NW Anjani. }\end{array}$ & $\begin{array}{l}\text { Penggambaran sosok Sakti yang } \\
\text { merupakan figur utama di sebuah } \\
\text { pondok pesantren merupakan } \\
\text { permainan elemen maksud. } \\
\text { Dengan menyampaikan informasi } \\
\text { yang akan menguntungkan secara } \\
\text { eksplisit dan jelas, hal itu } \\
\text { menggambarkan kecenderungan } \\
\text { dari pihak media. Kata utama yang } \\
\text { berarti terbaik dan terpenting } \\
\text { (nomor satu) mengarah } \\
\text { penggambaran seseorang dilakukan } \\
\text { dengan kata dan tujuan tertentu. }\end{array}$ \\
\hline 4. & $\begin{array}{c}\text { Leksikon } \\
\text { dan Koherensi }\end{array}$ & $\begin{array}{l}\text { Kendati terus menunjukan } \\
\text { optimisme, pasangan Ali- } \\
\text { Sakti } \\
\text { belum besungguhnya } \\
\text { lega. } \quad \text { Tetap bernapas } \\
\text { ada }\end{array}$ & $\begin{array}{l}\text { Mereka dibatasi gerak-geriknya } \\
\text { dalam pemberitaan ini. Di satu sisi } \\
\text { digambarkan bahwa mereka telah } \\
\text { melewati tahap pengumpulan KTP, } \\
\text { namun di sisi lain masih ada }\end{array}$ \\
\hline
\end{tabular}




\begin{tabular}{|c|c|c|c|}
\hline & & $\begin{array}{l}\text { kemungkinan mereka } \\
\text { gagal menjadi calon. ... } \\
\text { Dari jumlah yang } \\
\text { dikumpulkan, harus tersisa } \\
\text { setidaknya } 50.513 \\
\text { dukungan. Padahal, pola } \\
\text { verifikasi faktual nanti } \\
\text { juga berbeda.... }\end{array}$ & $\begin{array}{l}\text { kemungkinan untuk gagal. } \\
\text { Penggunaan kata hubung padahal } \\
\text { untuk menunjukkan pertentangan. } \\
\text { Padahal merupakan bagian dari } \\
\text { koherensi yang menghubungkan } \\
\text { dua fakta, yakni jumlah } \\
\text { pengumpulan KTP yang dilakukan } \\
\text { oleh sakti dan fakta proses } \\
\text { verifikasi faktual yang bisa saja } \\
\text { menggagalkan mereka. }\end{array}$ \\
\hline 5. & Skema & - & $\begin{array}{l}\text { Skema story dipakai dalam } \\
\text { pemberitaan ini. Skema ini } \\
\text { memiliki dua subkategori. Dalam } \\
\text { pemberitaan ini, kategori pertama } \\
\text { yaitu proses atau jalannya peristiwa } \\
\text { pengumpulan KTP pendukung dan } \\
\text { verifikasi faktual yang melahirkan } \\
\text { dua kemungkinan. Subkategori } \\
\text { kedua ialah komentar yang } \\
\text { didominasi oleh Tim Pemenang } \\
\text { Ali-Sakti }\end{array}$ \\
\hline
\end{tabular}

Pasangan Ali-Sakti menjadi lainnya dan didominasi oleh satu-satunya pasangan independen pemberitaan diri (advertorial) sosok dalam Pilgub NTB 2018. Dalam Ali BD. Selain itu, sebagai pasangan pemberitaan, Lombok Post independen, Ali-Sakti diharuskan menggambarkan mereka sebagai untuk mendapatkan dukungan pasangan yang anti akan sumbangan, sebanyak 325.968 suara agar bisa namun memiliki saldo rekening mendaftarkan diri. Jumlah itu terbanyak dibandingkan kandidat bukanlah hal yang sedikit, oleh lainnya, yakni sebanyak Rp10 miliar. karena itu mereka ditonjolkan Jumlah berita pasangan ini paling sebagai pasangan Pilgub NTB 2018 banyak dibandingkan kandidat yang banyak didukung oleh rakyat 
NTB. Tak hanya itu, lomba sepak bola (Ali-Sakti Cup) yang mereka adakan sebagai salah satu bentuk kampanye pun disorot oleh Lombok Post. Pada pemberitaan itu, mereka dicitrakan sebagai sosok yang mengayomi, mudah berbaur, dan mendengar aspirasi masyarakat, di antaranya kaula muda, kaum ibu, kaum bapak.

Tabel 7

Ringkasan Analisis Teks Berita Kandidat Pilgub NTB Tahun 2018

\begin{tabular}{|c|c|c|c|c|}
\hline No. & Judul Berita & Tema & Skema & Elelemen Wacana \\
\hline 1. & $\begin{array}{l}\text { Ali ke Bayan, Suhaili } \\
\text { ke Gangga (Sama-sama } \\
\text { Tebar Janji Surga) }\end{array}$ & $\begin{array}{l}\text { Persaingan antara } \\
\text { dua kandidat }\end{array}$ & $\begin{array}{c}\text { Skema } \\
\text { peristiwa }\end{array}$ & $\begin{array}{l}\text { Bentuk kalimat, } \\
\text { praanggapan, } \\
\text { metafora, koherensi } \\
\text { pembeda, kata ganti, }\end{array}$ \\
\hline 2. & $\begin{array}{l}\text { Suhaili-Amin } \\
\text { Disambut Meriah di } \\
\text { Janapria }\end{array}$ & $\begin{array}{ll}\text { Eksistensi } & \text { Suhaili } \\
\text { dan Amin } & \end{array}$ & Sum & $\begin{array}{l}\text { Leksikon, ekspresi, } \\
\text { semantic }\end{array}$ \\
\hline 3. & $\begin{array}{l}\text { Suhaili-Amin Siap } \\
\text { Lanjutkan } \\
\text { Pembangunan (Salah } \\
\text { Pilih Pemimpin, NTB } \\
\text { Taruhannya) }\end{array}$ & $\begin{array}{l}\text { Suhaili dan Amin, } \\
\text { pasangan yang tepat } \\
\text { memimpin NTB }\end{array}$ & Sumr & $\begin{array}{l}\text { Bentuk kalimat, } \\
\text { metafora, detil, } \\
\text { leksikon, koherensi } \\
\text { kondisional }\end{array}$ \\
\hline 4. & $\begin{array}{l}\text { Suhaili-Amin Calon } \\
\text { Paling Komplet } \\
\text { (Kenyang Pengalaman, } \\
\text { Bergelimang Prestasi) }\end{array}$ & $\begin{array}{l}\text { Keunggulan calon } \\
\text { kandidat Suhaili- } \\
\text { Amin }\end{array}$ & $\begin{array}{l}\text { Skema } \\
\text { person }\end{array}$ & $\begin{array}{l}\text { Leksikon, grafis, } \\
\text { koherensi pembeda, } \\
\text { metafora }\end{array}$ \\
\hline 5. & $\begin{array}{l}\text { Ahyar-Mori Jawara } \\
\text { Instagram }\end{array}$ & $\begin{array}{l}\text { Ahyar-Mori } \\
\text { pasangan yang } \\
\text { unggul dalam } \\
\text { platform media } \\
\text { sosial Instagram. }\end{array}$ & Summary & $\begin{array}{l}\text { Leksikon, ekspresi, } \\
\text { praanggapan, bentuk } \\
\text { kalimat, latar }\end{array}$ \\
\hline 6. & $\begin{array}{l}\text { Program Ahyar-Mori, } \\
\text { Satu Desa Satu Dokter } \\
\text { (Bukan Tebar Pesona, }\end{array}$ & $\begin{array}{l}\text { Pendeksripsian } \\
\text { program janji kerja. }\end{array}$ & Story & $\begin{array}{l}\text { Koherensi, detil, } \\
\text { bentuk kalimat, } \\
\text { leksikon, metafora, }\end{array}$ \\
\hline
\end{tabular}




\begin{tabular}{|c|c|c|c|c|}
\hline & $\begin{array}{ll}\text { Jabarkan } & \text { Program } \\
\text { Nyata) } & \end{array}$ & & & $\begin{array}{l}\text { maksud, } \\
\text { praangaapan }\end{array}$ \\
\hline 7. & $\begin{array}{lr}\text { Ahyar-Mori } & \text { Jamin } \\
\text { Pemerataan } & \\
\text { Pembangunan } & \text { (Bangun } \\
\text { Seluruh } & \text { NTB, } \\
\text { Ampenan } & \text { Hingga } \\
\text { Sape) } & \end{array}$ & $\begin{array}{l}\text { Infromasi visi dan } \\
\text { misi } \\
\text { menyeluruh } \\
\text { rata. }\end{array}$ & $\begin{array}{l}\text { Skema } \\
\text { peran } \\
\text { (Role } \\
\text { Schemas) }\end{array}$ & $\begin{array}{l}\text { Metafora, leksikon, } \\
\text { kata ganti, bentuk } \\
\text { kalimat, detil. }\end{array}$ \\
\hline 8. & $\begin{array}{l}\text { Ahyar-Mori Nyatakan } \\
\text { Diri Kuasai Panggung } \\
\text { Debat (Konsisten } \\
\text { Paparkan Data) }\end{array}$ & $\begin{array}{l}\text { Menonjolkan } \\
\text { pernyataan } \\
\text { keunggulan diri dari } \\
\text { pihak AMAN. }\end{array}$ & $\begin{array}{l}\text { Skema } \\
\text { peristiwa } \\
\text { (Event } \\
\text { Schemas) }\end{array}$ & $\begin{array}{l}\text { Detil, latar, leksikon, } \\
\text { koherensi pembeda, } \\
\text { maksud }\end{array}$ \\
\hline 9. & $\begin{array}{l}\text { Atur Siasat, Zul dan } \\
\text { Rohmi Bagi Diri }\end{array}$ & i kampanye & Sumi & Leksikon, maksud \\
\hline 10. & $\begin{array}{l}\text { Zul Blusukan Bersama } \\
\text { Relawan Hijau (Orang } \\
\text { Pintar Pantas Jadi } \\
\text { Gubernur) }\end{array}$ & $\begin{array}{l}\text { Bentuk kampanye } \\
\text { dialogis yang cerdas }\end{array}$ & $\begin{array}{l}\text { Skema } \\
\text { person } \\
\text { (Person } \\
\text { Schemas) }\end{array}$ & $\begin{array}{l}\text { Metafora, leksikon, } \\
\text { latar, koherensi, } \\
\text { grafis }\end{array}$ \\
\hline 11. & $\begin{array}{l}\text { Rohmi Prioritaskan } \\
\text { Beasiswa Perempuan } \\
\text { (Bisa Berbuat Banyak } \\
\text { untuk Daerah) }\end{array}$ & $\begin{array}{l}\text { Eksistensi Rohmi } \\
\text { sebagai representasi } \\
\text { perempuan NTB }\end{array}$ & $\begin{array}{l}\text { Skema } \\
\text { person } \\
\text { (Person } \\
\text { Schemas) }\end{array}$ & $\begin{array}{l}\text { Latar, leksikon, } \\
\text { ekspresi, koherensi }\end{array}$ \\
\hline 12. & $\begin{array}{l}\text { Zul-Romhi } \text { Munculkan } \\
\text { Ide-ide Pembangunan } \\
\text { (Banyak } \quad \text { Konsep } \\
\text { Aplikatif) }\end{array}$ & $\begin{array}{l}\text { Pasangan ini elegan, } \\
\text { bijaksana, cerdas. }\end{array}$ & Sto & $\begin{array}{l}\text { Maksud, ekspresi, } \\
\text { praanggapan, latar, } \\
\text { kata ganti, koherensi }\end{array}$ \\
\hline 13. & $\begin{array}{l}\text { Ali BD: Jangan Hanya } \\
\text { Seremoni } \quad \text { (Sikap } \\
\text { Damai Bukan di } \\
\text { Upacara) }\end{array}$ & $\begin{array}{l}\text { Ungkapan pikiran } \\
\text { dan perasaan Ali } \\
\text { BD }\end{array}$ & $\begin{array}{l}\text { Skema } \\
\text { diri (Self } \\
\text { Schemas) }\end{array}$ & Bentuk kalimat \\
\hline 14. & $\begin{array}{l}\text { Ali-Sakti Cup Ditutup } \\
\text { Pengukuhan Relawan } \\
\text { Gerakan Politik Rakyat }\end{array}$ & $\begin{array}{l}\text { Penyelenggaraan } \\
\text { kegiatan Ali-Sakti } \\
\text { Cup }\end{array}$ & Summary & $\begin{array}{l}\text { Ekspresi, leksikon, } \\
\text { koherensi, maksud }\end{array}$ \\
\hline
\end{tabular}




\begin{tabular}{|c|l|l|l|l|}
\hline & $\begin{array}{l}\text { (Gde Sakti: Saya Ingin } \\
\text { Lebih Dekat dengan } \\
\text { Anak-anak Muda) }\end{array}$ & & & \\
\hline 15. & $\begin{array}{l}\text { Ali-Sakti Rp 10 Miliar, } \\
\text { AMAN Rp 40 Juta } \\
\text { (Ali-Sakti Tidak } \\
\text { Terima Sumbangan) }\end{array}$ & $\begin{array}{l}\text { Perbedaan materi } \\
\text { dua kandidat }\end{array}$ & Story & $\begin{array}{l}\text { Detil, latar, } \\
\text { koherensi }\end{array}$ \\
\hline 16. & $\begin{array}{l}\text { Bawaslu Tak Tegas, } \\
\text { Ali-Sakti Berang } \\
\text { (Pengawasan Dianggap } \\
\text { Berat Sebelah) }\end{array}$ & $\begin{array}{l}\text { Pertentangan antara } \\
\text { Bli-Sakti dan }\end{array}$ & Summary & $\begin{array}{l}\text { Bentuk kalimat, } \\
\text { leksikon, metafora, } \\
\text { koherensi, } \\
\text { pengingkaran }\end{array}$ \\
\hline
\end{tabular}

Pada analisis 20 teks berita keempat kandidat gubernur NTB tahun 2018 yang dirilis oleh Lombok Post, setiap pasangan memiliki tema utama tersendiri, sebagai berikut:

a. Suhaili-Amin memiliki pengalaman memimpin paling banyak dibandingkan pasangan lainnya.

b. Ahyar-Mori mendapat dukungan dari banyak parpol, mereka aktif di Instagram, serta memiliki visi-misi dan data empiris yang membuat mereka unggul.

c. Zul-Rohmi memiliki strategi kampanye yang kreatif dan dialogis.
Mereka adalah pasangan yang bijak dan pintar (berintelektual tinggi). Rohmi digambarkan sebagai representasi perempuan NTB yang sukses dengan pendidikan yang tinggi.

d. Ali-Sakti merupakan pasangan independen, karena itu perihal materi lebih ditonjolkan dan digambarkan sebagai pasangan yang mengayomi dan peduli.

Berdasarkan analisis teks, ditemukan bahwa adanya keberpihakan dan strategi wacana. Hal itu termanifestasikan ke dalam beberapa wujud kebahasaan, yakni dilihat pada struktur teks wacana yang ditampilkan Lombok Post dalam merepresentasikan kandidat Pilgub NTB 2018. Sedangkan 
berdasarkan tema, yang dominan ditampilkan mengarah pada penonjolan citra positif setiap kandidat. Kemudian dari superstuktur, Lombok Post mengemas alur berita dengan skema yang beragam, namun sering menggunakan skema summary dan story. Selanjutnya pada stuktur mikro, berdasarkan latar, detil maksud, dan praanggapan mendukung citra positif setiap kandidat yang digambarkan oleh pihak Lombok Post.

Berdasarkan keseluruhan teks berita yang telah dianalisis, Lombok Post cenderung menampakkan citra positif keempat kandidat Pilgub NTB 2018. Pemilihan kata yang dipakai oleh Lombok Post dominan menggunakan kata berkonotasi positif seperti disambut meriah, Jawara Instagram, banyak konsep aplikatif, dan figur utama di pondok pesantren. Hal itu dapat menggambarkan pandangan positif media terhadap setiap kandidat dalam pemberitaan. Adapun elemen yang kerap kali hadir ialah detil, praanggapan, bentuk kalimat, koherensi, leksikon, dan metafora.
Sementara elemen wacana seperti latar, maksud, kata ganti, grafis, dan ekspresi sedikit ditemukan.

Kecenderungan Lombok Post membentuk citra positif setiap kandidat merefleksikan adanya berbagai kemungkinan. Keberpihakan tersebut berkemungkinan sejalan dengan hal-hal yang ditonjolkan pada pemberitaan setiap kandidat Pilgub NTB 2018. Hal itu dituangkan dalam penulisan teks berita, baik pada judul maupun isi berita, baik secara langsung ataupun tidak langsung. Berdasarkan hasil analisis keseluruhan berita, ditemukan bahwa Lombok Post cenderung menampilkan citra positif dengan menonjolkan keunggulan masing-masing dalam memberitakan setiap kandidat Pilgub NTB 2018. Perbandingan antara citra positif dan negatif pemberitaan setiap kandidat sangat sedikit. Untuk mengetahui apakah aktor berita direpresentasikan positif atau negatif dalam pemberitaan haruslah dengan menganalisis semua bagian berita. 


\section{Penutup}

Berdasarkan hasil analisis 20 teks berita pemilihan Gubernur dan Wakil Gubernur NTB tahun 2018 berdasarkan struktur AWK van Dijk, dapat disimpulkan hal-hal sebagai berikut.

Pertama, berdasarkan segi representasi atau penggambaran keempat kandidat, diperoleh gambaran diri (citra diri) setiap kandidat Pilgub NTB yang cenderung positif. Kedua, berdasarkan sisi kognisi sosial penulis berita surat kabar Lombok Post, unsur politik-ideologis penulis berita terlihat secara eksplisit dan implisit keberpihakannya pada subjek berita dalam pemberitaan. Salah satunya dalam merepresentasikan keempat kandidat Pilgub NTB 2018, penulis berita Lombok Post membentuk citra positif keempat pasangan dengan menonjolkan keunggulan setiap kandidat melalui praktik wacana. Dalam pada itu, perihal bagaimana dan mengapa beritai tu dihadirkan oleh penulis, tidak terlepas adanya praktik kekuasaan. Misalnya, pada calon kandidat Ali-Sakti, didominasi oleh berita advertorial (pemberitaan diri) atau penggambaran latar belakang pendidikan calon kandidat ZulRohmi secara detail. Ketiga, berlandaskan pandangan paradigma kritis yang memandang bahwa wartawan dan media tidak akan bisa netral dalam pemberitaannya, ditemukan bahwa Lombok Post berada pada posisi seperti itu. Tatkala memberitakan dua pihak, baik itu berseteru atau dibandingkan, terdapat keberpihakan dari Lombok Post pada salah satu pihak. Meskipun tidak ditampakkan secara eksplisit, kecenderungan sepihak itu bisa diketahui dengan membaca, merenungi, dan menganalisis teks berita secara seksama. Keempat, sebagai catatan tambahan, ditemukan kecenderungan lebih pada representasi dua pasangan kandidat Pilgub NTB 2018, yaitu pasangan Ahyar-Mori dan Ali-Sakti. Hal itu terbukti pada ruang pemberitaan yang lebih banyak. Selain itu, penggunaan bahasa yang cenderung hiperbola dibandingkan pemberitaan kandidat lainnya. 


\section{Daftar Pustaka}

Eriyanto. 2009. Analisis Wacana: Pengantar Analisis Teks Media. Yogyakarta: Penerbit Lkis Group.

Humaira, Hera Wahdah. 2018. Analisis Wacana Kritis (AWK) Model Teun A. Van Dijk pada Pemberitaan Surat Kabar Republika. Jurnal Penelitian Bahasa dan Sastra Indonesia serta Pembelajarannya Volume 2, No. 1 (2018).

Jamaludin, Asep, Ermanto Ermanto, dan Novia Juita. 2016. Pemberitaan Peristiwa Politik Pilgub Sumatera Barat Periode 2016-2021 Tinjauan Analisis Wacana Kritis Perspektif Teun A. Van Dijk dalam Media Online Portal Harian Singgalang. Jurnal Pendidikan Bahasa dan Sastra Indonesia Volume 2, No. 2 (2016).

Jayanti, Fitria Anugrah. 2014. "Analisis Wacana pada Pemilihan Gubernur Sulawesi Selatan Periode 2013-2018 di Kota Makassar". Makassar: Universitas Hasanuddin.

Mahsun. 2017. Metode Penelitian Bahasa: Tahapan Strategi, Metode, dan Tekniknya. Jawa Barat: Raja Grafindo Persada.

Nikmah, Miftahun. 2014. "Pilpres 2014 pada Rubrik Tajuk Rencana di Surat Kabar Suara Merdeka (Sebuah Analisis Wacana Kritis Model Taun.
Van Dijk". Thesis Universitas Diponegoro.

Nurassyiyah, Siti, Ermanto E., dan Novia Juita. 2014. Wacana Berita Politik Pilkada Kota Padang Periode 2014-2019 dalam Media Online Portal Harian Singgalang Kajian Analisis Wacana Kritis Perspektif Teun A. Van Dijk. Jurnal Bahasa dan Sastra Volume 2, No. 2 (2014).

Payuyasa, I Nyoman. 2017. Analisis Wacana Kritis Model Van Dijk dalam Program Acara Mata Najwa di Metro TV. Jurnal Hasil Penelitian Vol 5 , November.

Rani, Abdul, Arifin, dan Martutik. 2006. Analisis Wacana: Sebuah Kajian Bahasa dalam Pemakaian. Jawa Timur: Bayumedia Publishing.

Schriffin, Deborah, Tannen, Deborah, dan Hamilton, Heidi E. 2001. The Handbook of Discourse Analysis. United Kingdom: Blackwell Publishers.

Wati, Beti W. 2014. "Analisis Wacana Kritis Berita Sosial dan Politik Surat Kabar Kedaulatan Rakyat". Yogyakarta: Skripsi UNY.

Wodak, Ruth dan Meyer, Michael. 2001. Methods of Critical Discourse Analysis. London: SAGE Publications Ltd 